\title{
DNA Barcoding Tanaman Daluga (Cyrtosperma spp) dari Kepulauan Sangihe Berdasarkan Gen matK (DNA Barcoding Daluga Plant (Cyrtosperma spp) of Sangihe Island Based on matK Gene)
}

\author{
Eka Julianti ${ }^{1)^{*}}$, Arthur Pinaria ${ }^{1)}$, Edy F. Lengkong ${ }^{1)}$, Beivy J. Kolondam ${ }^{2)}$ \\ 1)Program Studi Agronomi, Pasca Sarjana Universitas Sam Ratulangi, Kampus UNSRAT \\ Manado 95115 \\ 2) Jurusan Biologi FMIPA Universitas Sam Ratulangi, Kampus UNSRAT Manado 95115 \\ *Email korespondensi: ekajulianti89@yahoo.com
}

Diterima 23 Juli 2015, diterima untuk dipublikasikan 27 Agustus 2015

\begin{abstract}
Abstrak
Tanaman daluga (Cyrtosperma spp.) termasuk dalam famili Araceae (talastalasan), umbinya berpotensi sebagai tanaman pangan alternatif karena mempunyai nilai gizi yang tinggi. Tanaman ini banyak terdapat di Kepulauan Sangihe. Penelitian ini dilakukan untuk mengetahui DNA barcoding daluga hijau, kuning dan belang-belang dengan menggunakan gen matK (maturase K). Ekstraksi DNA menggunakan Genomic DNA Mini Kit Plant (Geneaid), amplifikasi DNA menggunakan Kit PCR 5x FirePol Master Mix (Solis Biodyne) dan sepasang primer universal yaitu matK-3F-r (5'CGTACAGTACTTTTGTGTTTACGAG 3') dan matK-1R-f (5'ACC CAGTCCATCTGGAAATCTTGGTTC3'). Hasil penelitian menunjukkan bahwa tanaman daluga hijau, daluga kuning, dan daluga belang-belang dari Kepulauan Sangihe memiliki sekuens DNA yang identik (kemiripan 100\%). Daluga yang diteliti memiliki kemiripan sekuens dengan sampel di NCBI yaitu dengan Cyrtosperma macrotum (99,88\%), Podolasia stipitata (99,50\%), Dracontium polyphyllum (99,38\%), Pycnospatha arietina (99,38\%) dan Dracontioides desciscen (99\%). Dari hasil penelitian ini dapat disimpulkan bahwa DNA barcoding tanaman daluga dari kepulauan Sangihe berdasarkan gen matK belum dapat membedakan variasi intraspesies.

Kata kunci: daluga, dalugha, Cyrtosperma spp.
\end{abstract}

\begin{abstract}
Daluga (Cyrtosperma spp.) plant belongs to the family Araceae, the corm is potential as an alternative food because it has a high nutritional value. The plant is widely available in Sangihe Island. This study aimed to determine the DNA barcoding of green daluga, yellow daluga and mottled daluga using matK gene (maturase K). The DNA extraction used Genomic DNA Mini Kit Plant (Geneaid) and DNA amplification used the Kit PCR 5x FirePol Master Mix (Solis Biodyne) and universal primers matK-3F-R (5' CGTACAGTACTT TTGTGTTTACGAG 3') and matK-1R-f (5'ACCCAGAAATGGATCTCTTCCTGG TTC3'). The result showed that the green daluga, yellow daluga and mottled daluga from Sangihe Islands were identical (100\% similarity). Daluga from Sangihe had similarities with the sample sequences in NCBI, namely Cyrtosperma macrotum (99.88\%), Podolasia stipitata (99.50\%), Dracontium polyphyllum (99,38\%) Pycnospatha arietina (99.38\%) and Dracontioides desciscen (99\%). From these results it could be concluded that DNA barcoding of daluga plant from Sangihe based on the matK gene could not distinguish variations intraspesies.
\end{abstract}

Keywords: daluga, dalugha, Cyrtosperma spp. 


\section{PENDAHULUAN}

Daluga (Cyrtosperma spp) adalah nama lokal yang diberikan oleh masyarakat untuk tanaman talas rawa yang terdapat di Kepulauan Sangihe. Umbi daluga berpotensi sebagai tanaman pangan alternatif pengganti beras sejak puluhan tahun lalu karena umbinya mengandung karbohidrat yang tinggi yaitu sebesar $83,44 \%$ (Lumba 2012). Nama umum tanaman daluga dalam bahasa Inggris disebut Giant Swamp Taro (Talas Rawa Raksasa), Swamp Taro (Talas Rawa) dan Gallan (Lim 2015).

Genus Cyrtosperma memiliki jumlah spesies paling sedikit yaitu 12 spesies yang tersebar di Papua, Semenanjung Malaya, Filipina, Kalimantan, Sumatra, Jawa dan Oseania. Tanaman daluga merupakan satu-satunya spesies dari genus ini yang umbinya dapat dikonsumsi oleh manusia (Jackson, 2008). Hasil penelitian terbaru di Federated States of Micronesia mengatakan bahwa di daerah Micronesia dan sekitarnya terdapat 37 kultivar Crytosperma dan masing-masing kultivar memiliki karakter morfologi berbeda (Rao et al. 2014).

Tanaman daluga banyak terdapat di daerah Kepulauan Sangihe yaitu kepulauan yang berbatasan dengan wilayah selatan negara Filipina. Beberapa tempat merupakan habitat asli yang ditumbuhi tanaman daluga seperti Tamako, Manganitu Selatan dan Tatoareng (Julianti 2011). Tanaman daluga dapat tumbuh dengan baik di lahan basah dan tanah yang sering tergenang air payau dengan kadar garam berkisar 0,59 ppt - 1,91 ppt dan kadar keasaman $(\mathrm{pH})$ 6,9 - 9,8 (Ratag et al. 2013). Screening in vivo menunjukkan bahwa beberapa kultivar tanaman daluga dapat mentoleransi kadar garam sampai 5 ppt (Rao et al. 2014 b). Tanaman daluga juga dapat mentoleransi suhu maksimum $38^{\circ} \mathrm{C}$ dan minimum $15,5^{\circ} \mathrm{C}$ (Manner 2011). Daluga merupakan salah satu tanaman pangan lokal yang mempunyai nilai penting bagi masyarakat Kepulauan Sangihe dan sekitarnya sehubungan dengan dampak perubahan iklim serta dalam menunjang program pemerintah untuk meningkatkan ketahanan dan kemandirian pangan (Lintang et al. 2012), tetapi saat ini tanaman daluga belum dibudidayakan secara luas oleh masyarakat bahkan rawa tempat tumbuh tanaman daluga telah dikonversi menjadi sawah dan pemukiman (Ratag et al. 2013).

Petani di Kepulauan Sangihe mengenal tiga jenis daluga berdasarkan warna tangkai daunnya yaitu daluga hijau, daluga kuning dan daluga belang-belang. Ketiga jenis tanaman daluga tersebut memiliki beberapa karakter morfologi dan rasa umbi yang berbeda. Penelitian tentang tanaman daluga yang ada di Kepulauan Sangihe masih tergolong sedikit. Untuk pengembangan dan budidaya tanaman daluga diperlukan berbagai data pendukung salah satunya yaitu identifikasi status genetik tanaman daluga. Mengidentifikasi dan mempertahankan keragaman genetik tanaman daluga sangat penting untuk menjadi dasar pertimbangan dalam menyusun strategi konservasi, pemuliaan, pengelolaan dan pemanfaatan sumber daya genetik tanaman daluga secara berkelanjutan.

Teknologi DNA barcoding telah dikembangkan untuk mengidentifikasi dan menganalisis keragaman genetik spesies baik hewan maupun tumbuhan secara molekuler yaitu dengan menggunakan sekuens/potongan DNA pendek. DNA barcoding dapat digunakan dalam bidang taksonomi dan filogenetik tumbuhan untuk hasil identifikasi tumbuhan yang lebih akurat dibandingkan dengan identifikasi secara morfologi (Kress dan Erickson 
2008 a). Consortium for the Barcoding of Life (CBoL) Plant Working Group merekomendasikan dua gen yang terdapat dalam kloroplas untuk digunakan dalam DNA barcoding tumbuhan yaitu gen rbcL (ribulose-1,5biphosphate carboxylase oxygenase) dan gen matK (maturase K) (Kress et al. 2010).

Gen matK lebih banyak digunakan dalam berbagai penelitian dibandingkan gen rbcL karena gen matK dapat membedakan sampai tingkat spesies. Gen matK juga memiliki kecepatan evolusi yang tinggi dan urutan sekuens yang lebih bervariasi (Barthet 2006) sehingga gen matK dinilai lebih baik dan lebih akurat dalam mengindentifikasi dan membedakan suatu spesies (Kolondam et al. 2012).

Publikasi ilmiah mengenai DNA barcoding tanaman daluga dari Sangihe dalam Barcode of Life Database (BOLD) System belum ditemukan, selain itu juga belum ada publikasi ilmiah yang mencantumkan sekuens DNA gen matK tanaman daluga di GenBank dalam situs National Center for Biotechnology Information (NCBI). Berdasarkan halhal yang telah diuraikan di atas maka perlu dilakukan penelitian mengenai DNA barcoding tanaman daluga dari Kepulauan Sangihe berdasarkan urutan sekuens gen matK, sehingga dapat digunakan sebagai data identitas molekuler tanaman pangan alternatif khas dari Kepulauan Sangihe dan sebagai acuan untuk melestarikan tanaman daluga.

\section{METODE \\ Isolasi DNA Tanaman Daluga}

Daun tanaman daluga hijau, daluga kuning, dan daluga belangbelang masing-masing diambil $50 \mathrm{mg}$, kemudian digerus dengan penggerus tabung Eppendorf. Sampel yang sudah disiapkan dalam tabung Eppendorf diisolasi menggunakan Genomic DNA Mini Kit Plant (Geneaid) sesuai dengan prosedur manual yang disediakan perusahaan dengan menambahkan buffer lisis proteinase $\mathrm{K}$, kemudian diinkubasi selama 10 menit pada suhu $65^{\circ} \mathrm{C}$. Setelah itu sel dipisahkan dengan sentrifugasi selama 1 menit pada 5000 rpm kemudian ditambahkan buffer dan disentrifugasi selama 2 menit pada $10000 \mathrm{rpm}$. Supernatant yang diperoleh kemudian disaring melalui kolom filter. DNA total yang diperoleh dicuci dari sisa proteinprotein dan garam. Selanjutnya dielusikan 2-5 menit dan disentrifugasi selama 30 detik pada 10000 rpm (Vogelstein dan Gillespie 1979, Geneaid).

\section{Amplifikasi dengan Polimerase Chain Reaction (PCR) \\ Reaksi PCR dilakukan dalam} volume total $50 \mu \mathrm{L}$. Komposisi dari reaksi PCR yaitu: $10 \mu \mathrm{L} 5 \mathrm{x}$ FirePol Master Mix (Solis BioDyne), $1 \mu \mathrm{L}$ primer forward matK-3F-r (5' CGT ACA GTA CTT TTG TGT TTA CGA G 3'), 1 $\mu$ l primer reverse matK-1R-f (5' ACC CAG TCC ATC TGG AAA TCT TGG TTC 3'), $3 \mu \mathrm{L}$ templat DNA (sampel), dan $35 \mu \mathrm{L}$ air (deionisasi, bebas nuklease). Tahapan dalam proses amplifikasi PRC meliputi denaturasi DNA (awal) pada suhu 95으 selama 120 detik, (i) denaturasi pada suhu 95ㄷ $\mathrm{C}$ selama 30 detik, (ii) perlekatan primer (primer annealing) pada suhu $52 \stackrel{\circ}{\circ}$ selama 30 detik, (iii) DNA extension pada suhu $72^{\circ} \mathrm{C}$ selama 50 detik. Ketiga tahapan (i,ii,iii) berlangsung dalam siklus sebanyak 35 kali dan tahap akhir final extension pada suhu $72^{\circ} \mathrm{C}$ selama 60 detik (Kolondam, 2015). Proses amplifikasi dilakukan dengan alat PCR Personal (Biometra). Proses sekuensing dilakukan oleh penyedia jasa sekuensing First Base Laboratories Sdn Bhd Malaysia.

\section{Analisis Data}

Hasil sekuensing DNA berupa kromatogram disunting menggunakan software Geneious v5.6. (Drummond et al. 2012) dengan langkah sebagai 
berikut: bagian awal dan akhir sekuens DNA dihapus kira-kira 30 bp (primer). Hasil sekuensing menggunakan primer reverse (matK-1R-f), dan dilakukan proses reverse and complement, kemudian dipadukan dengan hasil sekuens primer forward (matK-3F-r) menggunakan Multiple Sequence Comparison by Log-Expectation (MUSCLE) yang terintegrasi dalam Genious v5.6. Sekuens gen matK diidentifikasi melalui Barcode of Life Database (BOLD)

System

(Ratnasingham dan Hebert 2007). Penjajaran sekuens DNA dilakukan dengan menggunakan MUSCLE bertujuan untuk mengetahui adanya perbedaan nukleotida antara masingmasing sampel tanaman daluga. Sekuens diubah ke dalam bentuk format FASTA (Fast Aligment) dan dibandingkan dengan sekuens kerabat terdekat yang terdapat di Gen Bank menggunakan Basic Local Alignment Search Tool (BLAST) (http://blast.ncbi.nlm.nih.gov). Penjajaran sekuens DNA tanaman daluga dengan kerabat terdekatnya dilakukan dengan menggunakan software Multalin pada situs http://multalin.toulouse.inra.fr./multalin/ (Corpet 1998, Lawodi et al. 2013). Penentuan reading frame untuk penjajaran asam amino dan analisis dilakukan dengan Geneious v5.6. Pohon filogenetik direkonstruksi juga dengan menggunakan Geneious v5.6.

\section{HASIL DAN PEMBAHASAN}

Isolasi DNA merupakan tahap pertama dari berbagai teknologi analisis DNA. yang bertujuan untuk memisahkan DNA dari bahan lain seperti protein, lemak dan karbohidrat. Hasil isolasi dan amplifikasi gen matK tanaman daluga hijau (kode HJU), daluga kuning (kode KNG) dan daluga belang-belang (kode BLG) memperlihatkan pola pita yang jelas dan tunggal ditunjukkan dengan elektroforesis yang divisualisasikan dengan UV-Transluminator (Gambar 1). Pita DNA tunggal artinya DNA yang diperoleh tersebut utuh atau tidak ada smear ketika DNA dielektroforesis. DNA yang berkualitas baik dicirikan oleh pita DNA yang terlihat tebal dan bersih bila divisualisasikan foto gel elektroforesis (Ardiana 2009). Hal ini menjadi penting karena pada proses sekuensing DNA yang masih utuh akan memberikan hasil yang lebih akurat.

Berdasarkan ukuran DNA ladder (1kb) pita DNA yang terbaca berukuran diantara 800 bp - 900 bp. Hasil sekuensing produk PCR matK untuk semua sampel menghasilkan kromatogram yang berkualitas tinggi dengan nilai High Quality (HQ) yaitu > 90\%. Penjajaaran menggunakan algoritma Muscle (Edgar 2004) dalam software Geneious (Drummond et al. 2012) menunjukkan bahwa ketiga sekuens sampel DNA tanaman daluga hijau, daluga kuning dan daluga belang identik (kesamaan 100\%) (Gambar 2). Hal ini menunjukkan bahwa tanaman daluga hijau, daluga kuning dan daluga belang termasuk dalam satu spesies yang sama yaitu walaupun dalam karakter morfologinya terdapat beberapa perbedaan. Area gen matK yang diamplifikasi dengan sepasang primer matK-3F-r dan matK1R-f belum dapat membedakan variasi intraspesies diantara tanaman daluga dari Kepulauan Sangihe. Variasi intraspesies mungkin masih dapat dilihat jika menggunakan sekuens gen matK utuh karena panjang gen matK sekitar 1500 bp, tetapi dalam penelitian ini hanya menggunakan gen matK parsial yang panjangnya hanya sekitar 800-900 bp sesuai dengan daerah penempelan primer matK-3F-r dan matK-1R-f. Sekitar 600 bp sekuens gen matK tanaman daluda yang belum bisa dibaca.

Banyak primer didesain untuk mengamplifikasi fragmen gen matK, tetapi kesulitan sering dihadapi ketika menggunakan primer yang telah tersedia saat ini (Fazekas et al. 2008) karena tiap primer tersebut mempunyai kelebihan dan 
kekurangan. Walaupun beberapa primer telah dikembangkan tetapi sering tidak cocok untuk beberapa spesies (Jing et al. 2011). Hal ini disebabkan karena variasi genetik intraspesies sangat kecil. Selain itu untuk mengetahui variasi intraspesies yang lebih akurat dibutuhkan dua atau lebih kombinasi lokus sehingga dapat menghasilkan data yang lebih signifikan (Newsmaster dan Ragupathy 2009, Tallei dan Kolondam 2014).

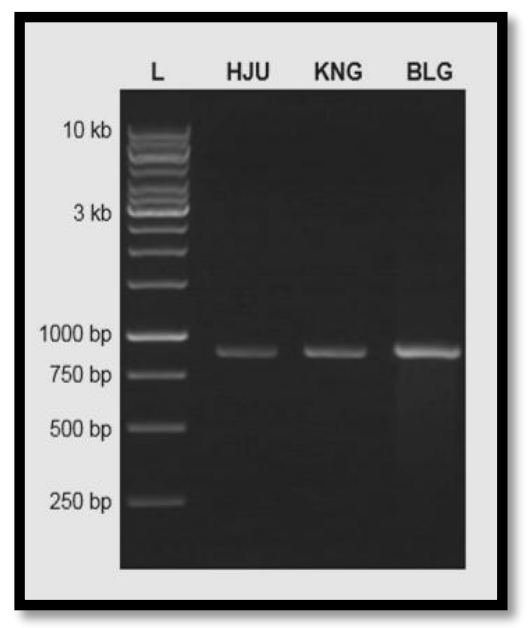

Gambar 1. Visualisasi hasil elektroforesis gen matK tanaman daluga. Keterangan: L: $1 \mathrm{~kb}$ DNA ladder, HJU: daluga hijau, KNG: daluga kuning, BLG: daluga belang.

Sekuens dalam bentuk format FASTA dari tanaman daluga dibandingkan dengan lima kerabat terdekat di NCBI dan penjajarannya dilakukan dengan program Multalin. Sekuens tanaman daluga mempunyai tingakat kemiripan dengan beberapa sekuens di NCBI yaitu dengan Cyrtosperma macrotum (99,88\%), Podolasia stipitata (99,50\%), Dracontium polyphyllum (99,38\%), Pycnospatha arietina (99,38\%) dan Dracontioides desciscen (99\%).

Sekuens tanaman daluga Sangihe yang disejajarkan dengan kerabat terdekat (Gambar 3) dan dari genus yang sama yaitu Cyrtosperma macrotum dengan nomor aksesi
AM920572.1 memiliki perbedaan satu basa nukleotida pada urutan nukleotida 455, dengan Pedolasia stipitata AM920574 memiliki empat basa nukleotida berbeda pada urutan 178, 373, 444 dan 455, dengan Pycnospatha arietina AM920573.1 berbeda lima basa nukleotida pada urutan 373, 455, 530, 586 dan 795, dengan Dracontium polyphyllum AM920569.1 berbeda lima basa nukleotida pada urutan $155,373,455$, 586 dan 650 serta dengan Dracontioides desciscen AM920576.1 berbeda delapan basa nukleotida pada urutan 240, 289, 365, 373, 438, 455, 586, dan 560.

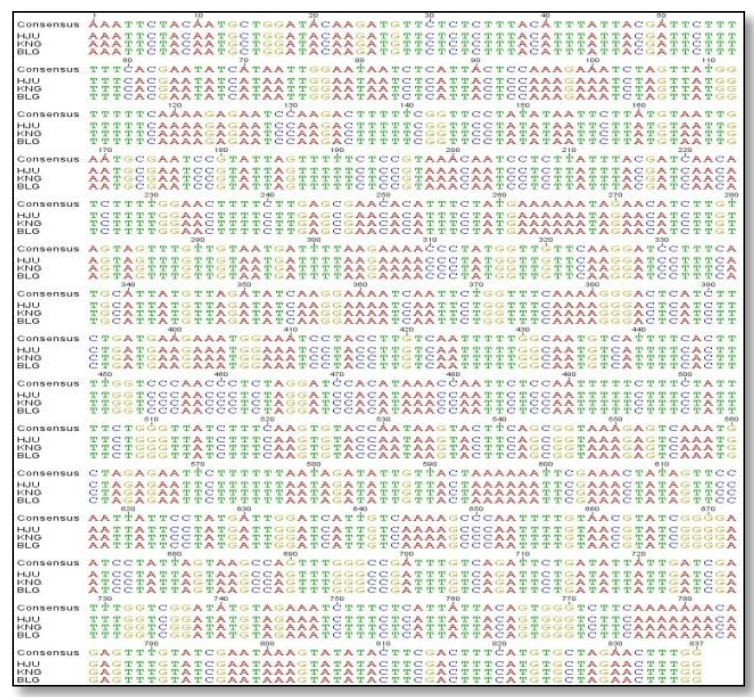

Gambar 2. Hasil Penjajaran Sekuens DNA barcoding Tanaman Daluga Hijau, Daluga Kuning dan Daluga Belang-belang berdasarkan Gen matK.

Satu basa nukleotida berbeda terdapat diantara daluga Sangihe dan Cyrtosperma macrotum tetapi triplet tersebut memiliki sususan asam amino yang sama yaitu serin $($ TCC $\rightarrow$ TCT; Serin $\rightarrow$ Serin). Perubahan basa nukleotida tanpa pengubahan asam amino yang dikodekan disebabkan oleh mutasi sinonim, mutasi ini tetap menghasilkan asam amino yang sama meskipun satu pasang basa nukleotida berubah (Zhou et al. 2010). Mutasi sinonim merupakan perubahan sekuens basa nukleotida yang tidak 
menyebabkan perubahan aktivitas pada produk yang dikode oleh gen tersebut. Hal ini muncul akibat satu nukleotida diganti oleh nukleotida yang lain. Bila perubahan satu basa nukleotida ini tidak mengubah asam amino, maka fungsi dari protein tidak akan berubah (Corebima 2010).

Daluga Sangihe dengan Pedolasia stipitata memiliki tiga susunan asam amnino berbeda yaitu $\mathrm{TCC} \rightarrow \mathrm{TTC}, \mathrm{GTT} \rightarrow \mathrm{GCT}, \mathrm{CAC} \rightarrow \mathrm{AAC}$; (Serin $\rightarrow$ Fenilalanin, Valin $\rightarrow$ Alanin, Histidin $\rightarrow$ Aspargin), dengan Dracontium polyphyllum dua asam amino berbeda yaitu GTT $\rightarrow$ GCT, ATT $\rightarrow$ ACT; $\quad$ (Valin $\rightarrow$ Alanin, Isoleusin $\rightarrow$ Treonin), dengan Pycnospatha arietina hanya terdapat satu asam amino berbeda yaitu ATT $\rightarrow$ ACT; (Isoleusin $\rightarrow$ Treonin), serta dengan Dracontioides desciscen terdapat 4 asam amino yang berbeda yaitu $\quad$ CTT $\rightarrow$ ATT, $\quad$ TGT $\rightarrow$ TAT, CAT $\rightarrow$ TAT, $\quad$ ATT $\rightarrow$ ACT; (Leusin $\rightarrow$ Isoleusin, Sistein $\rightarrow$ Tirosin, Histidin $\rightarrow$ Tirosin, Isoleusin $\rightarrow$ Treonin).

Berubahnya basa nukleotida yang kemudian mengubah asam amino yang dikodekan disebabkan oleh mutasi titik (Hawkes et al., 2004). Mutasi titik (point mutation) merupakan mutasi yang melibatkan penggantian satu pasang basa (subtitusi basa), dimana satu basa pada sekuens DNA diganti dengan basa yang berbeda. Mutasi ini dapat menyebabkan berapa hal tergantung dari letak mutasinya pada gen (Corebima 2010). Menurut Lehninger (1982) mutasi dapat diartikan sebagai perubahan permanen yang akan bersifat menurun pada genom (gen-gen atau urutan nukleotida) suatu organisme.

Pohon filogenetik (Gambar 4) menunjukkan tanaman daluga dari Sangihe, Cyrtosperma macrotum (AM920572.1), dan Podolasia stipitata (AM920574.1) dan Phycnospatha arietina (AM920573.1) merupakan kelompok monofiletik. Kelompok monofiletik adalah kelompok organisme yang terdiri dari nenek moyang yang sama dan semua turunannya memiliki hubungan yang sangat dekat (Hidayat dan Puncoro, 2006) sedangkan Dracontium polyphyllum (AM920569.1) dan Dracontioides desciscen (AM920576.1) termasuk dalam kelompok tersendiri yang tetuanya berkerabat dengan tetua dari Daluga Sangihe, Cyrtosperma macrotum, Podolasia stipitata dan Phycnospatha arietina.

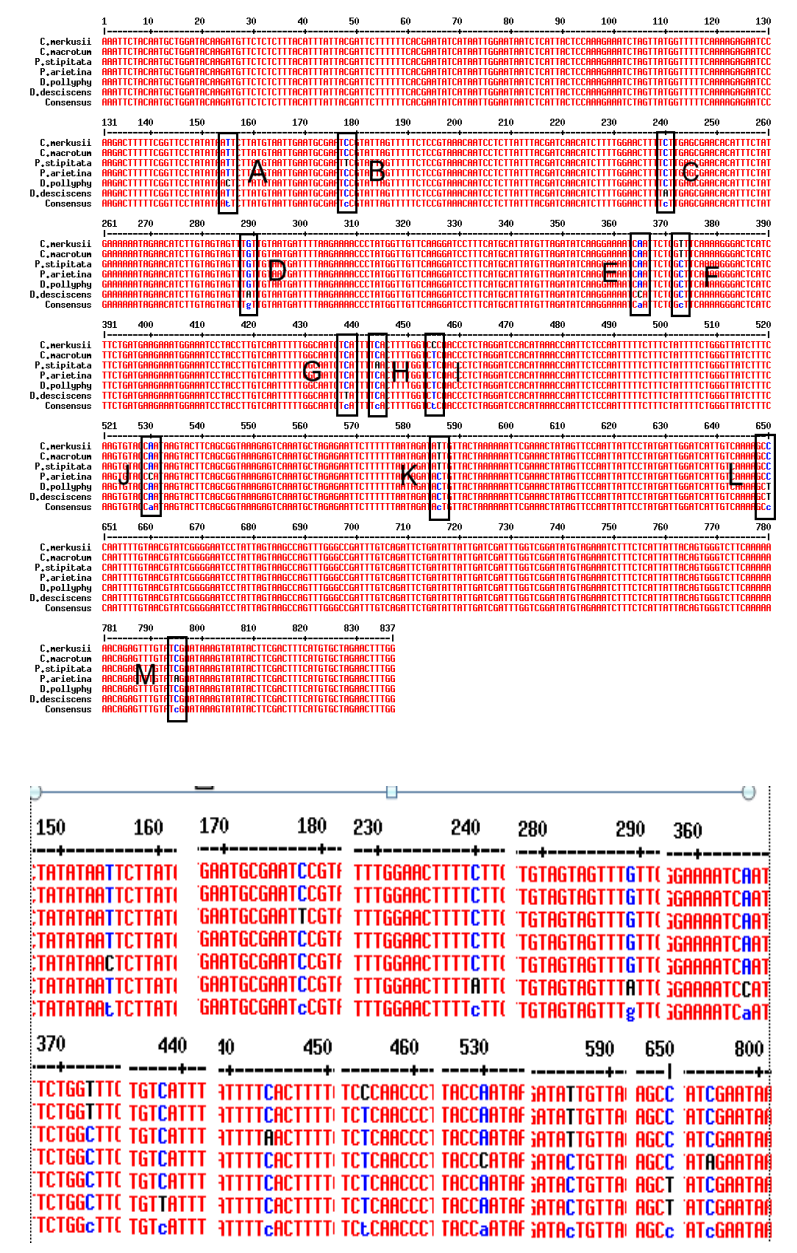

Gambar 3. Penjajaran Sekuens DNA Tanaman Daluga (Cyrtosperma spp) dengan Kerabat Terdekat di NCBI dengan menggunakan Multalin serta perbesaran lokasi perbedaan nukleotida berturut-turut $A, B, C, D, E$, F, G, H. I, J, K, L dan M.

Jarak genetik ( $p$-discance) yang dihitung dengan software Geneious 
(Tabel 1) menunjukkan jarak genetik paling dekat adalah antara daluga Sangihe dengan Cyrtosperma macrotum yaitu 0,001. Pasangan sekuens yang mempunyai jumlah perubahan terkecil diantara mereka disebut neighbors artinya pasangan tersebut memiliki hubungan yang sangat dekat (Dharmayanti et al, 2011).

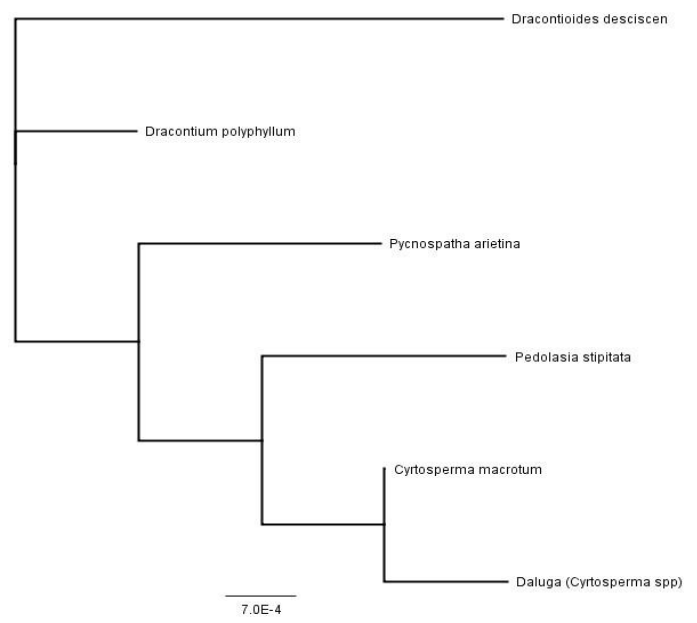

Gambar 4. Pohon filogenetik tanaman daluga dan beberapa kerabatnya berdasarkan gen matK.. Konstruksi filogenetik menggunakan Geneious v5.6.

Tabel 1. Matrix p-distance sekuens gen matK tanaman daluga (Cyrtosperma merkusii) dengan kerabat terdekatnya dari GeneBank

\begin{tabular}{|c|c|c|c|c|c|c|}
\hline & Cmorotum & Dolugo & D. desciscen & D. polyphylum & P. stipititoto & P. orititino \\
\hline \multicolumn{7}{|l|}{ Cmorotoum } \\
\hline Doluge & 0,001 & & & & & \\
\hline D. dextisten & 0,008 & 0,010 & & & & \\
\hline D. poypanylum & 0,005 & 0,006 & 0,006 & & & \\
\hline P. stipitito & 0,004 & 0,005 & 0,010 & 0,006 & & \\
\hline P. orititino & 0,005 & 0,006 & 0,008 & 0,005 & 0,006 & \\
\hline
\end{tabular}

\section{KESIMPULAN}

Tanaman daluga hijau, daluga kuning, dan daluga belang-belang (Cyrtosperma spp) dari Sangihe memiliki urutan sekuens gen matK yang sama atau dentik 100\%. Tanaman daluga yang diteliti dari Sangihe memiliki kemiripan sekuens dengan sampel di NCBI yaitu dengan Cyrtosperma macrotum (99,88\%), Podolasia stipitata $(99,50 \%)$, Dracontium polyphyllum (99,38\%), Pycnospatha arietina $(99,38 \%)$ dan Dracontioides desciscen (99\%). DNA barcoding berdasarkan gen matK belum dapat membedakan variasi intraspesies di antara tanaman daluga hijau, daluga kuning, dan daluga belang-belang dari Kepulauan Sangihe. Disarankan menggunakan kombinasi beberapa lokus DNA untuk membedakan variasi intraspesies tanaman daluga Sangihe.

\section{DAFTAR PUSTAKA}

Ardiana D (2009) Teknik isolasi DNA genom tanaman pepaya dan jeruk dengan menggunakan modifikasi Buffer Ctab. Buletin Teknik Pertanian 14 (1):12-16

Barthet MM (2006) Expression and function of the chloroplastencoded gene matK. Virginia Polytechnic Institute and State University. Blacksburg

Corebima AD (2010) Genetika Mutasi dan Rekombinasi. Surya Peneerbit Gemilang. Malang

Corpet F (1998) Multiple sequence alignment with hierarchical clustering. Nucleate Acids Research 16 (22):10881-10890

Dharmayanti NLPI (2011) Filogenetika molekuler: metode taksonomi organisme berdasarkan sejarah evolusi. Wartazoa 21(1):1-10

Drummond AJ, Ashton B, Buxton S, Cheung M, Cooper A, Duran C, Field $M$, Heled J, Kearse $M$, Markowitz S, Moir R, StonesHavas S, Sturrock S, Thierer T, Wilson A (2012) Geneious v5.6. Biomatters. New Zealand.

Edgar RC (2004) MUSCLE: Multiple sequence alignment with high accuracy and high throughout. 
Nucleate Acid Research 5:1792-1797

Fazekas AJ, Burgess KS, Kesanakurti PR, Graham SW, Newmaster SG, Husband BC, Percy DM, Hajibabaei M, Barret SCH (2008) Multiple multilocus DNA barcodes from the plastid genome discriminate plant species equally well. Plos One 3:2802

Hawkes NJ, Janes RW, Hamingway J, Vontas J (2004) Detection of resistance-associated point mutation of organophosphateinsentive acetylcholines in the olive fruit fly Bactrocera olea (Gmlin) Pesticide Biochemistry and Physiology 81:151-163

Hidayat T, Pancoro A (2006) Sistematika dan filogenetika molekuler. Kursus Singkat Aplikasi Perangkat Lunak PAUP dan MrBayes untuk Penelitian Molekuler. SITH. ITB

Jackson GVH (2008) Generation guidelines major aroids. Secretariat of the Pacific Community (SPC). Fiji. http://www cropgenebank.sgrp .cgiar.org.

Jing Y, Xue JH, Zhou SL (2011) New universal matK primers for DNA barcoding angiosperms. Journal of Systematics and Evolution 49(3):176-188

Julianti E (2011) Kajian morfologi maluga (Cyrtosperma merkusii (Hassk) Shcott) di Kepulauan Sangihe. Skripsi Jurusan Biologi FMIPA Unsrat. Manado

Kolondam BJ (2012) Barcode DNA $r b c L$ dan matK aglaonema (Aglaonemasp.), anthurium gelombang cinta (Anthurium plowmanii) dan anggrek payus Limondok (Phaiustan carvilleae). Tesis Program Pascasarjana UNSRAT, Manado

Kolondam BJ (2015) Applying matK gene for identification of
Liliopsida plant species from North Sulawesi through Bold System. International Journal of Applied Biology and Pharmaceutical Technology 6 (2):242-245

Kress WJ, Erickson DL (2008) DNA barcodes: Genes, genomics and bioinformatics. Departement of Botany. Proceedings of The National Academy of Sciences USA 105:2761-2762

Kress WJ, Erickson DL, Swenson NG, Thompson J, Uriarte M, Zimmer JK (2010) Advances in the use of DNA barcodes to build a community phylogeny for tropical trees in a Puerto Rican forest dynamics plot. Plos One 5 (11)

Lehninger AL (1982) Principles of Biochemistry. Wort Pub. New York

Lim TK (2015) Edible medicinal and non medicinal plants. Volume 9: Modified Stems, Roots, Bulbs. Spinger Science + Business Media Dordrecht

Lintang M, Layuk P, Bahtiar (2012) Potensi pangan lokal dalam membangun kemandirian pangan di Kabupaten Kepulauan Sangihe. Laporan BPTP Sulawesi Utara.

Lawodi EN, Tallei TE, Mantiri FR, Kolondam BJ (2013) Variasi genetik tanaman tomat dari beberapa tempat di Sulawesi berdasarkan gen matK. Pharmacon 2 (4):114-121

Lumba R (2012) Kajian pembuatan beras analog berbasis tepung umbi daluga (Cyrtosperma merkusii (Hassk) Schott). Skripsi Jurusan Teknologi Pertanian. Fakultas Pertanian. Universitas Sam Ratulangi. Manado

Manner HI (2011) Farm and forestry production and marketing profile for giant swamp taro (Cyrtosperma chamissionis) in 
speciality crops for Pacific Island agroforestry. Permanent Agriculture Resources (PAR). C. R. Elevitch (Ed) Halualoa, Hawai

Newsmaster SG, Ragupathy S (2009) Testing plant barcoding in a sister complex of Pantropical acacia (Mimosoideae, Fabaceae). Molecular Ecology Resources 9: 172-180

Rao S, Taylor M, Jokhan A (2014) A descriptor list for giant swamp taro (Cyrtosperma merkusii) and its cultivars in the federated states of Micronesia. TELOPEA 16:95-117

Ratag SP (2013) Analisis faktor-faktor lingkungan habitat tanaman daluga (Cyrtosperma merkusii (Hassk) Schott) di Kabupaten Kepulauan Sangihe. Disertasi Pascasarjana Universitas Brawijaya. Malang

Schmidt H (2003) Phylogenetic trees from large databasets. naugural-Dissertation, Dusseldorf University. http://www.bi.unidusseldorf.de/ hschmidt/publ/schmidt2003/phd thesis.pdf. Diakses pada 20 Agustus 2015
Tallei TE, Kolondam BJ (2014) DNA barcoding of Sangihe nutmeg (Myristica fragrans) using matK gene. Hayati Journal of Biosciences 22 (1):41-47

Vogelstein B, Gillespie D (1979) Genomic DNA mini kit (plant). for research use only. Protocol Proceeding Natural Academy Science USA 76: 615

Weiss KM (1995) Genetic variation and human diseases: Principle and evolution approaches. Cambridge University Press. Cambridge

Zhou T, Gu W, Wilke CO (2010) Detecting positive and purifying selection at synonymous sites at yeast and worm. Molecular Biology Evolution 27(8):19121922 